\title{
Is Green the New Red? Marxism, Ecology, and Contemporary Architectural Theory
}

\author{
Curtis Swope
}

check for updates

Citation: Swope, Curtis. 2021. Is Green the New Red? Marxism,

Ecology, and Contemporary Architectural Theory. Humanities 10: 45. https://doi.org/10.3390/ h10010045

Received: 16 November 2020 Accepted: 26 February 2021 Published: 8 March 2021

Publisher's Note: MDPI stays neutral with regard to jurisdictional claims in published maps and institutional affiliations.

Copyright: (C) 2021 by the author. Licensee MDPI, Basel, Switzerland. This article is an open access article distributed under the terms and conditions of the Creative Commons Attribution (CC BY) license (https:// creativecommons.org/licenses/by/ $4.0 /)$.
Department of Modern Languages and Literatures, Trinity University, 1 Trinity Place, San Antonio, TX 78212-7200, USA; cswope@trinity.edu

\begin{abstract}
This essay examines the role of Marxist concepts in recent architectural theories of ecology using two architecture firms, Estudio Teddy Cruz and Sauerbruch Hutton (SH), as case studies. In their writings, Cruz and SH mobilize the critique of capital, a dialectical materialist understanding of history, and the Frankfurt School's critique of functionalist culture for the theorization of sustainable design. Their work has two vital ramifications for current sustainability discourses in two different fields which this essay seeks to bridge. For Marxist theorists concerned about ecology but averse to Western Marxism because of its supposed idealism, Cruz and SH show anew the importance of aesthetic concerns to conceptions of the environment. For design scholars accustomed to thinking of Marxism as having been absorbed into broader debates about cultural studies, the architects' theories have the potential to recentralize the left-wing inheritance through its adaptation to concerns of ecology. In addition, in the essay's conclusion, I reflect briefly, as a suggestion for further research, on how Cruz's and SH's architectural practice and theories might productively be analyzed in light of the terms of the Adorno-Benjamin debate of the 1930s over the political status of the cultural products of capital. Can eighty-year old discussions of the potentially revolutionary and retrograde qualities of mass cultural objects be relevant to radical thought in the age of climate change.
\end{abstract}

Keywords: contemporary architecture; ecology; Marxism; Sauerbruch Hutton; Teddy Cruz; Frankfurt School; green architecture; Theodor Adorno; Walter Benjamin; Bertlolt Brecht; Ernst Bloch; Berlin; Tijuana; materia

This article shows how two key voices in contemporary architectural theory, the Anglo-German firm Sauerbruch Hutton (SH) and the Guatemalan-born US architect Teddy Cruz, have begun to adapt the conceptual tools of the Western Marxist critical theory of the Frankfurt School, now standard reading in architecture programs in Europe and the United States, to the exigencies of a world in which ecological concerns are paramount (Jay 1984, pp. 10-11). The architects' nascent "greening" of this "red" intellectual legacy has two ramifications, which it is the purpose of this article to explain. The first is that Cruz's and SH's mobilization of the critique of capital, dialectical materialist understandings of history, and the Frankfurt School's critique of functionalist culture for the theorization of sustainable design can help make less diffuse a Marxism that, in the architectural culture of 1980s and 1990s, had become diluted (Khan et al. 2013; Cupers 2014). The second is that these architects' theories can help recentralize aesthetics in Marxist discourses on ecology in which Western Marxists such as Theodor Adorno, Ernst Bloch, and Walter Benjamin have been derided as too idealist to aid in the formation of useful concepts for radical ecological thought.

These arguments are developed in three sections. The first and longest analyzes the Marxist dimensions of Cruz's and SH's theories in light of the status of Marxism in recent architectural discourse. The second shows how their theoretical Marxism, resting on architecture's simultaneous existence as representation and reality, art and science, can help reintroduce questions of aesthetics to Marxist debates on ecology. The final section briefly examines Cruz's and SH's most recent architectural practice to indicate that architecture in the age of climate change might well be subject to dichotomies of critique and complicity 
similar to those that undergirded the Adorno-Benjamin debate of the 1930s over the radical political potential of objects produced as mass culture in capitalist systems.

As will have been inferred from the repeated use of the word, "debates," this essay is meant to intervene in theoretical discussions about sustainability and to help foreground the role Marxism can play in such discussions. The essay does not offer a template for sustainable design, but rather makes clearer the utility of a key critical tradition for formulating frameworks within which sustainable design might be conceived. Though Cruz and SH do not necessarily mention Adorno, Benjamin, Brecht, or Bloch in their writings or put themselves directly into dialogue with these thinkers, the traces of the Western Marxist conceptual armature-from the primacy of use value, to the need to generate aesthetic programs from the base up, to the critique of commodity fetishism-are to be found throughout the architects' theoretical program. Their theories thus form part of a long critical tradition which they, through their consideration of key problems of sustainability, are beginning to adjust for the twenty-first century. Given the constraints that architects and planners face as they deal with clients, community institutions, and multiple layers of government from the local to the national, the architects' built work reflects their theoretical frameworks in highly complex ways. My article is confined almost entirely to the theoretical side of their output, though Cruz's and SH's highly dialectical approach would demand a concomitant account of their practice.

Thus, I would like to note here that this article is very much meant as a first step in a longer line of inquiry into the status of Marxism in contemporary architectural theory and practice. Cruz and Sauerbruch Hutton were selected precisely because they have been in the vanguard of theorizing their architecture in terms of the necessity for major structural shifts and the inadequacy of smaller scale attempts of ecological and economic reform. In this sense, their theoretical frameworks serve as initial case study into a much larger question. My essay does not pretend to be a survey of ecological Marxism in contemporary architecture, but rather makes arguments that begin to clarify the terms in which such a survey might be conducted and underscore its most important implications.

\section{Marxism, Cultural Studies and the Theories of Cruz and SH}

Marxisms of various shades have been part of architectural theory's push over the last generation towards greater interdisciplinarity, but have tended to become diluted or concealed. In primary source volumes of theoretical writings, Marxist thinkers have often been conceptually positioned such that their Marxism is subsumed into discussions of cultural studies or of the continued relevance of modernism and postmodernism as analytical frameworks. Joan Ockman's Architecture Culture (1993) placed writings by Michel Foucault and Henri Lefebvre next to texts by post-Modernist architects Robert Venturi and Denise Scott Brown (Ockman 1993). Neil Leach's groundbreaking volume of primary sources, Rethinking Architecture: A Reader in Cultural Studies (1997), included writings by Frankfurt School Marxists such as Theodor Adorno, Ernst Bloch, and Walter Benjamin in a section entitled, "Modernism" rather than "Marxism" or even "critical theory." Other avowed, if never doctrinaire, Marxists like Fredric Jameson were placed in the section headed "Postmodernism" (Leach 1997).

Certainly, the emergence of a cultural studies approach to architecture and the continued debates over the value of modernism and postmodernism were trends and discussions within which the legacy of the Frankfurt School, apart from its embeddedness in specifically Marxist debate, had a crucial role to play. It should not be forgotten, though, that Martin Jay has seen a primary contribution of the Frankfurt School thinkers and their mid-century French counterparts such as Lefebvre and Foucault, in the creation of a Western Marxism that, ever since Györgi Lukács's History and Class Consciousness (1923) recentralized questions of aesthetics against Leninist theories of art as a "reflection" of political economy (Jay 1984, pp. 10-11). K. Michael Hays, the leading scholar on Marxist architect Hannes Meyer and central theoretical force at Harvard's Graduate School of Design in the 1990s and early 2000s, has been keen to acknowledge the specifically Marxist dimensions of 
cultural critiques that grew from the Frankfurt School thinkers. Hays included Michel Foucault, Fredric Jameson, and Henri Lefebvre in his volume of writings on architecture since 1968. In his standard-work, Modernism and the Posthumanist Subject (1995), Hays says of Benjamin, Bloch, Adorno, and Siegfried Kracauer, that their work is essential to understanding the history of inter-War modernism and that their texts represent "perhaps the most significant, sustained attempt to thematize the changed conceptualization of objects [at that time] and the changed relation of subjects in a systematic and aesthetic critical theory" (Hays 1995, p. 8). Before the publication of this book, Hays had already, in his editorial work at Assemblage, been instrumental in asserting the continued value of Marxist theory even in the deconstructionist 1980s. The genesis for such a positive view of Frankfurt School Marxism in architectural debate over the past thirty-five years is to be found in the work of the Italian architectural historians Manfredo Tafuri and Francesco Dal Co, whose research in the 1970s used Benjamin's and Lukács's Marxist concepts of history to create a new social-historical context for modernist architectures developed in response to technological and urban changes driven by market forces. In their Modern Architecture (1976), Western Marxism became an essential conceptual armature for understanding the encounter of architecture and twentieth century modernity (Tafuri and Dal Co). Thus, central Western Marxist concerns such as the experience of commodity culture, fetish relationships, feelings of alienation in urban environments, and the de-professionalization of the arts have been subsumed into discussions of the nature of the architectural object and the characteristics (i.e., the rise of mass culture) that have been seen to separate twentieth century modernity from its nineteenth century predecessor. Marxism has thus become part of a diverse intellectual inheritance that architectural theory has taken as flexibly appropriable and adaptable to the designing of buildings in the age of global capital.

Cruz's practice on the San Diego-Tijuana border from 2001 to the present has involved intensive sociological and ecological research from San Diego's rich exurbs and decaying ranch-house neighborhoods to Tijuana's informal settlements. He has designed childcare facilities and affordable housing complexes; his writing has ranged from the impressionistic to the programmatic and has largely been published in collections of essays by socially engaged contemporary architects. Cruz sees informal urbanism as a source of creative inspiration and is committed to remaking architecture's institutional apparatus accordingly. Indeed, his work at the beginning of the century has in many ways been path-breaking as evident in echoes of it now found among other architects (Owen et al. 2013). Cruz seeks through his work to remake patterns of everyday life and critique a focus on scientific standards which he sees as part of green architecture's new functionalism. In so doing, he points out the role of class disparities in perpetuating professional architecture's decadence and insists on the legibility of ecological disaster in urban landscapes and buildings themselves. His materialism distinguishes him from the phenomenological approach of some other ecologically minded architects (Neveu 2015; Hyde 2015). He defines architectural use value as the productive expression of need through the arrangement of space and seeks to bridge the best aspects of informal design (efficiency, human scale and creative focus on need) and of architectural expertise, a category he is at pains to redefine as knowledge of structure and form and of facilitation between citizens and institutions.

Cruz's mode of criticizing and subverting the architectural status quo relies on understanding potential revolutions as growing dialectically from material conditions. In his 2009 essay "A City Made of Waste," he traces the process of San Diego's decaying mid-century ranch houses' becoming disposable "waste" and their parts being recycled for dense settlements of low-wage factory, or maquiladora, workers on the edge of Tijuana:

"As new McMansion subdivisions update these older suburbs in San Diego, the first ring of suburbanization is being dismantled, piece by piece. Small bungalows are dismembered and their pieces given away to Mexican speculators. Thus the debris of Southern California's middle-class suburbs is recycled to build the new periphery of Tijuana". (Cruz 2009) 
This informal urban recycling is a capitalist exchange relationship in which bourgeois notions of dwelling are peeled away as collective patterns of living are subject to predatory capital. Cruz's design work, which includes a prefabricated steel frame with hinges that can flexibly accommodate recycled materials extracted from older houses and the renovation of a factory to make the frame itself, is an intervention in this nakedly capitalist process that takes the rawness of cross-border commodification of dwelling as a dialectical foundation for revolutionary architectural action. Cruz's path to sustainable architecture is through intervention in informal processes of exchange from which a new aesthetic of reuse might be extracted. Cruz thus shares with playwright Bertolt Brecht a fascination with capitalism's grossest distortions and the sense that the space of such distortions is also the locus of revolutionary intervention. As Andy Merrifield has pointed out, the notion of the capitalist city being "pregnant with its contrary" goes back to Marx and informed Henri Lefebvre's concepts of revolutionary urban action as early as his Introduction to Modernity of 1958 (Merrifield 2002). The economies of informal settlement-building, as a by-product of speculative excess, make new, non-capitalist urban policy thinkable. Such a policy is the first step toward the sustainable land use Cruz sees as impossible under free-market systems. Cruz, accordingly, re-envisions the role of the architect's agency; the designer becomes just one element of a revolutionary process rather than an autonomous agent of change. As Hays says of Brecht in Modernism and the Posthumanist Subject, "the subject [in his work] is no longer viewed as an originating agent of meaning, but as a variable and dispersed entity whose very identity and place are constituted in social practice" (Hays 1995, p. 5). Brecht is counted by Jay as a key Western Marxist and his dissolution of idealist subjectivity as a key Western Marxist construct (Jay 1984, pp. 3, 6, 416). A similarly stinging indictment of bourgeois architectural culture is evident in the selections by Ernst Bloch included in Neil Leach's 1997 primary source volume. Cruz resuscitates this overtly Marxist dimension of Bloch's and Brecht's thought to formulate a critical theory of architecture sustainability.

Analogous to this rethinking of architectural process is Cruz's disapproval of an approach that sees ecological solutions emerging from star architects' high-end design labs. Cruz instead believes, as did the Western Marxists whose theories came to be included in architectural theory readers, that architectural forms and their meanings should be derived from use value and on-the-ground economic processes. In his "Letter to the Profession of Architecture," he recounts his impressions of the renderings on display at the Venice Biennale of 2008:

"I thought of the huge divide between the architectures of excess displayed there and the economic precariousness of the world outside. It was unsettling to witness some of the most 'cutting-edge' architectural practices present themselves as silent props for the free market economic and political systems that were so wildly floundering that September". (Cruz 2011, p. 3)

Cruz makes a call for dispensing with the facade of visual experimentality as a sign of progressive architectural innovation and says instead that architects need to become agents in the remaking of economic models and of, another crucial Western Marxist concept, consciousness. Architecture must shift its institutional norms to combat consumerism, "fundamentally rethink everyday practices," and create "new modes of sociability and public culture" (Cruz 2011, p. 3). Architecture should forsake the visual articulation of technological novelty and instead work in response to emerging forms of urbanism that point to new social and economic arrangements.

This conviction forms the basis of Cruz's condemnation of a pseudo-ecological formalism that sees the architectural expression of technological efficiency as the core of environmentally responsible building. Again, from the "Letter to the Profession":

"it does not matter whether urban development is wrapped by the latest morphogenetic skin, pseudo neoclassical prop, or LEED-certified photovoltaic panels, if all these approaches continue to camouflage the most pressing problems of 
urbanization today. Without altering the exclusionary policies constructing the socio-economic and political ground of society, our profession will continue to be subordinated to the visionless environments defined by the bottom-line urbanism of the developer's spreadsheet and the neo-conservative politics and economics of a hyper-individualistic society premised upon a principle of ownership". (Cruz 2011, p. 4)

Eco-capitalist architecture's quantitative approach and its technologically driven environmentalism become for Cruz a formalism bereft of the revolutionary content necessary for real economic and environmental sustainability. This critique of top-down progressivism goes back at least to Brecht's and Bloch's rejection of modernist architecture (Heynen 1999). Cruz reveals here that the creation of built environments that are not "visionless" requires developing new institutions, new economies, and architectural forms that signal a reorganization of power that they embody and stem from. The aesthetic and the sustainable in architecture are conceived here as a unity.

These ideas also represent an extension of the thinking Theodor Adorno developed in his 1965 speech "Functionalism Today," which was published in translation in Oppositions in 1979 and reprinted in Leach's reader in 1997. As Cruz diagnoses architecture's problems in class terms, Adorno sees the underlying defects of midcentury building in the contradictions of the capitalist class: "The limits of functionalism to date have been the limits of the bourgeoisie in its practical sense" (Adorno 1997). For Cruz, the pseudo-materialism of developing formal gestures according to measurable ecological situations is in fact a bourgeois formalism that gives the architectural profession the illusion of creating buildings adequate to ecological problems. Adorno, for his part, concludes that

"a work [of architecture] must cut through the contradictions and overcome them, not by covering them up, but by pursuing them. Mere formal beauty, whatever that might be, is empty and meaningless; the beauty of its content is lost in the pre-artistic sensual pleasure of the observer". (Adorno 1997)

Cruz's theoretical work has similarly pursued an approach that locates architecture's value in the concrete content of the conditions of production and concrete use values that generate revolutionary potential. He extends Adorno's critique of formalism into the realm of sustainability in a way that brings the Western Marxist tradition of critical theory into connection with the potential for radically sustainable architectural practice.

Indeed, Cruz insists on the need to develop forms that articulate new kinds of economies by growing from architects', builders', planners', and users' coordinated intervention in systemic problems. A building's look and feel arises from engagement with moments of crisis which "can be traced to a specific conflict between ecologies, natural and artificial" (Cruz 2010a, p. 154). Absent this engagement, the creation of architectural forms will be "a mere camouflaging (and decoration at best) of selfish, oil-hungry urbanization from China to Dubai to New York to San Diego" (Cruz 2010a, p. 154). To imagine forms in such materialist terms is to echo Adorno's insistence on systemic change as a key to artistic innovation and Bloch's emphasis on the shaping of a new sense of place. For Cruz as for Bloch and Adorno, architecture's Formwollen must not remain superficial, but must be acknowledged as an integral part of a materialist approach to economy. What drives Cruz's thinking is the dual attention to economic and ecological distortions as a unity in architect-planners' attempts to give the built world new form.

Like Brecht before him, Cruz believes that such revolutionary forms are in a phase of emergence that cannot be dictated in advance by those (i.e., traditional architects) outside the processes at work. Humanitarianism that focuses on short-term relief of social injustices is insufficient. The radical urban interventions Cruz helps undertake in Tijuana and from which new forms of ownership and urbanism can grow show, in an echo of Adorno, that "radical proximity [to capitalist institutions] can produce new aesthetic categories, problematizing the relationship of the social, the political, and the formal" (Cruz 2009). Brecht's Mahagonny and Threepenny Opera delve into the heart of capitalism's 
commodification of the human body as a dialectical contribution to revealing capitalism's other. For Cruz, this necessarily becomes an environmental problem in a way that it had not been for Brecht. The economic and ecological crises of today are in his view also inherently cultural (Cruz 2010a, p. 161). Recent architecture's conception of forms as separate from the interrelated spheres of ecology and economy represent a betrayal of architecture's purpose. Places of material privation springing from global capitalism's economic and environmental crises are the breeding grounds for the unified pursuit of solutions to a set of architectural problems of which ecology is now recognized to be a fundamental part.

However, Cruz is careful to insist, somewhat against Adorno and instead following Nicolas Bourriaud's Relational Aesthetics, that "the role of creative production is no longer to present the possibility of unattainable alterity, but rather to create new ways of living and acting in everyday spaces and situations" (Cruz 2010b, p. 81). The formal aspect of the building is vision-changing, but is so through the shaping of actual human activity-the use of the building. The Roman architectural theorist Vitruvius's notion of utilitas is coeval for him with the venustas of new structures and cities just as, for Cruz, the ecological is connected to the production of everyday life. This reflects leading eco-Marxist John Bellamy Foster's desire, treated above, to refocus efforts on the production sphere, but does so by expanding the notion of production to include users' production of everyday life through the labor of dwelling and working in new structures. Seen from this perspective, Cruz's (and before him Adorno's) theories of architecture offer a riposte to eco-Marxism's refusal to see consumption (use) and production as part of an integrated dialectic whose two halves must be addressed as a unity. Cruz, following Zygmunt Bauman, also criticizes modernity's instrumentalism, which he sees represented in the massive, top-down planned housing projects of the $60 \mathrm{~s}$, but seeks at the same to retain a future-oriented definition of the political as the "capacity to anticipate a course of action" (Cruz 2010b, p. 76). The key to creating architectural forms is to intervene materially and formally in that course of action which, for Cruz, must by definition include concern for the ecological. His critical concept of architectural sustainability thus gains impetus from an engagement with key Western Marxist concepts.

In their theoretical writings, Sauerbruch and Hutton develop historical, ecological, and architectural sensibilities based on self-consciously socialist architectures. This is particularly evident in their dialectical approach to the relationship between present attempts to create a critical architecture and historical moments in which architecture sought such status. Their essays since 2000 have sought to develop a rationale for an architecture that can point to contradictions in neo-liberal economies and do as little harm to ecologies (and thus human chances for survival) as possible. A key to that rationale has been finding a dialectical balance between past architectural practices like the eco-alternativism and tenement reclamation movements of the 1970s, on the one hand, and the large-scale Fordist planning schemes of the 1950s and 60s, on the other. Their written work has been collected in volumes in 2006 and 2012 and ranges from prize-acceptance speeches to ruminations on architecture's critical capacity. Their most notable built work includes the Federal Environment Ministry building near the Bauhaus in Dessau and an expansion of an East German high rise for use as the headquarters of the social-housing bank GSW in Berlin, before the co-optation of the GSW by developers interests ("Wutmieter auf der Straße" 2011). The firm's dialectical sense of history and critique of formalist functionalism is drawn from the Western Marxist antipathy to the empty stylisticality of pared-down modernist facades; their ruminations on the bodies of buildings' users provide a path for reconceptualizing perception of the built world as political labor. The firm's lineage can be traced back to the firm of Peter and Alison Smithson who, in the early 1950s rebelled against the influence of Stalinist architectural precepts in the London city planning office (Highmore 2010). Their work coincided in many ways with the emergence of the New Left in Britain after 1956 and has been placed in connection to the theories of Marxist cultural theorist Raymond Williams (Highmore 2010). 
Architectural historian Barry Bergdoll traces in SH's work the attempt to unify "formal experiments" and "progressive social features" to make a discursive and material contribution to environmental thinking. This unifying of social and formal aspects of built work becomes, as Bergdoll describes it, part of an organic architectural process that weaves together creative labor and material necessity:

"There is a give and take between building and site as Sauerbruch Hutton sketch forms onto a building site to get to know its qualities and then in turn allow contours to be shaped by issues of energy production, urban situation, program and user experience, almost the way that winds and waves shape the earth". (Bergdoll 2009, p. 12)

This approach is reminiscent of Bloch's insistence in Das Prinzip Hoffnung that architectural forms grow from creative engagement with natural conditions and with the needs of "real people." This parallel can be extended too to considerations of the role of place in SH's work. Bloch calls for an architecture that eschews what he saw as Corbusier's abstract focus on etre humain in favor of forms that, in their connectedness to bodies and nature, create anew a sense of "home, contentment, Heimat" (Bloch 2003, p. 517). SH want their architecture to intervene in how senses of place are constructed through recognition of the place of human beings within ecologies. They eschew the merely visual, the "picturepostcard" aesthetic, and see identity as constructed in the sensory, bodily experience of buildings' users.

This by no means makes the firm anti-modern or anti-modernist. In their 2005 essay, "What does Sustainability Look Like," the architects explicitly criticize the ecological movement's anti-modern search for alternative cultures. This search is "anti-industrial, anti-urban and characterized by a yearning for some vague notion of a pre-civilized state" (Sauerbruch and Hutton 2006, p. 274). These rejectionists, SH explain in an earlier essay, "Modernity without Dogma," were, in the 1970s, among the most influential forces in the design schools of West Germany. They elided capitalism and modernity and saw in the large-scale planning schemes of Berlin's Gropiusstadt and the Märkisches Viertel professional architecture's corporatism and technology-fetishism. For SH, the alternativists' efforts represented the revival of an outmoded "craft tradition" that was in no way truly sustainable. Additionally, their mission was ripe for a commodification that in fact followed after the fall of the Berlin Wall: "The ideas that tended to be propagated by hippies in the past are now the domain of 'experts' who want to get to grips with them in a scientific manner. This approach emphasizes the quantifiable aspects of building rather than the qualitative ones" (Sauerbruch and Hutton 2006, p. 274). Sauerbruch and Hutton see the same reductive thinking at work in designations like the BREEAM and LEED certifications today that "are no more than compilations of functional requirements, directives on ways of working, summaries of measurable quantities" (Sauerbruch and Hutton 2006, p. 274). In this unexpected parallel critique, they see in the alternativist eco-movements of the 1970s and the housing bureaucracy of the post-Wall period a similarly "functionalist" disposition of the kind that Adorno argued against.

$\mathrm{SH}$ reject the notion that "environmental" forms can be developed directly from a consideration of environmentally friendly functions. The firm continues as such a longstanding left-wing critique of architectures that try to express and pre-program a building's purpose through forms (Lefebvre 1995, pp. 116-22). They echo Cruz in poking fun at buildings that rely on the cheap formal trick of trying to "look like" nature through biomorphic forms. For SH, such tricks paper over the inherently antagonistic presence of buildings within ecologies; architectural forms should be designed instead to allow users to feel and work, eat, dwell and play with a sense of that antagonism (Ingersoll 1996). This desire to expose industrial modernity's harmful effects explains $\mathrm{SH}^{\prime}$ s relatively sympathetic view of East German high-rise housing projects of the 60s and 70s, which they see as having accomplished just that-however unconsciously.

Sauerbruch and Hutton also critique the Left's reverence in the 1960s and 70s for the pre-Modernist city, particularly for informal living arrangements in the old tenements. This 
impulse has been subject to appropriation by the culture industry as the desire to overcome alienation has led to the conflation of a rhetoric of sustainability and a consumerist conservatism in which the words "organic," "fair trade," and "ecological" are false promises as well as totems in the liturgy of Berlin's officially sanctioned gentrification:

"The message [these words] broadcast[] is that you can have both: unbridled satisfaction and Ecological Correctness. Sustainability, here, is not a question of doing without, but of improved quality - quality that justifies a higher price and also placates the conscience. The classical cliché of luxury (old, monumental buildings, for example) comes together with added ecological value in an iconographic 'coherence' that does not require any explanation". (Sauerbruch and Hutton 2006, p. 275)

Ecology has been reduced to a buzzword lodged within the collective false consciousness of consumerism. SH's dialectical understanding of commodification becomes a basis for finding forms truer to architecture's fundamental mission of uniting aesthetic experience with useful spaces and solid structures. Form is not a separable surface, but must be seen as integral to utility and construction.

SH's call for an aesthetics of sustainability, based on "doing without" rather than "having it all," is not just a statement about the organization of a scaled-back political economy but represents a claim about the process through which architectural forms can be tied to radical agendas. This mission is a legacy of the work of Peter and Alison Smithson with whose firm Louisa Hutton got her start, just after hers and Sauerbruch's time at the Architectural Association School of Architecture in London in the early 1980s. It is a mission that has a closer connection to Marxism than Reyner Banham was willing to acknowledge either in his ground-breaking 1955 article on the New Brutalism, which took the Smithsons as a central example, or his book on the movement ten years later. Banham's article is a primary document offering insights into the nascent "crisis of modernism" that would structure debates in architecture for the fifteen years after (Mallgrave 2009, pp. 355-69). More than this, though, Banham's piece offers a snapshot of a moment of transition in architectural Marxism. Written shortly after Stalin's death, Banham's piece assumes that "communist" architects in Britain remain dogmatically oriented toward the Soviet Union and have themselves entered a moment of crisis as the Stalinist "architecture of traditions" gives way to a scientific approach more closely resembling social housing efforts in the capitalist West. He positions the Smithsons as "brutalist" provocateurs who radicalize the inheritance of Corbusier and Mies. However, Banham's retention of a highly disciplinary focus on specifically architectural influences entirely misses the Smithsons' affinities with the Marxist Williams and with the Western Marxist focus on the dialectical quality of privation that found expression in Team 10's return to the essentials of bodily human existence and the everyday social practices of the working class (Stanek 2013).

While leading scholars continue to parse out the lineage of the term Brutalism, efforts have also been made to locate the Smithson's work not so much in terms of historical labels, but in terms of their place in the intellectual ferment of the early 1950s in Britain (Vidler 2014). One line of thought follows Banham in seeing the Smithsons' work as a revival of high modernism's polemic verve against the staid doctrines of British Marxism (Webster 1997). However, according to Ben Highmore, in a recent close analysis of the Smithsons' design proposals from the early 1950s, the Smithsons' re-envisioning of the role of the architect at mid-century grew from a conviction that one of the central socio-aesthetic concerns of the time was the need "to recognize the ability of a [working-class] community to make lively living conditions out of impoverished means" a process the Smithsons saw as self-regulating and as "plac[ing] architectural practice on the back foot, suggesting that socially relevant architecture is not made on the drawing board, but actualized by the art of inhabitation" (Highmore 2010, p. 91).

The notion of privation or "doing without" has long had a central role to play in Western Marxism's dialectical notion of historical change, perhaps most succinctly encapsulated in Walter Benjamin's locating of revolutionary potential in the dreary Sunday 
afternoons of Berlin's proletarian district, a tradition extending back to Marx's "18th Brumaire" (Benjamin 2009). Though Highmore does not directly trace the Marxist lineage of such ideas in the Smithsons' thought, he does note the connection to Independent Group photographer Nigel Henderson's revival of Surrealism's aesthetic of found objects, a revival running parallel to the Situationists' similarly minded and more overtly Marxist work on mass culture and the changed nature of metropolitan modernity in 1950s Paris. Dirk van den Heuvel has shown, though, that the Smithsons' focus on the "ordinary" in the 1950s and into the 1960s was part of the increasingly flexible understanding of Marxism in the British New Left of the 1950s which, according to van den Heuvel, give important impetus to the rise of cultural studies through the work of Williams, who sought to develop a non-dogmatic neo-Marxism (Van den Heuvel 2013). It is this neo-Marxism, emerging alongside the Smithsons' ruminations on the ordinary that laid the groundwork for SH's injection of Western Marxist concepts into recent architectural debates on ecology. The firm's focus on the elemental and ordinary bodily experience of buildings thus has a heritage in mid-century Marxism ferment-a heritage far less surprising when we consider that the Smithsons in 1988 made a then highly anachronistic, given that era's focus on deconstructionism, call for a reconsideration of the legacy of architectural metabolism, a 1960s movement that had its roots in Marx's coinage of that very term to describe the dialectical relationship of labor and nature (Smithson and Smithson 1988; Swyngedouw 2005).

In accordance with this tradition, Sauerbruch and Hutton turn to the agency of buildings' everyday users to find a measure for the non-quantifiable quality of sustainability. Sustainability, for the firm, is deeply about the creation of a value that is measurable neither as a quantity of exchange nor through a set of architectural forms developed independent of users: "What an environment worth living in is ... can be measured only by our own, personal, sensory apparatus (Sauerbruch and Hutton 2006, p. 276). Architecture plays a role in an in-flux category like "user satisfaction at the workplace," which must be freed from its status as degraded buzzword by being linked to material use value. $\mathrm{SH}$, in their fleshing out of the importance of the body as a gauge of sustainability in architecture, now begin to develop a radically materialist concept of architectural sustainability that borders on the ontological: "we shouldn't just ask ourselves what sustainability looks like, but also what it feels like, what it sounds like, what it smells like, and ultimately what it really is: what is the character, the Wesen of sustainability?" (Sauerbruch and Hutton 2006, p. 277). Such body-based use value, without dismissing the role of consciousness, subverts idealist concepts of individual subjectivity in order to point to processes by which architectural forms might gain meaning as "sustainable" ones.

This is stands in contradiction to Foster's claim in Marx's Ecology that Western Marxism is too Hegelian to add anything to materialist debates about the environment and political economy. However, SH's view of modernity falls into line with Foster's as set forth in a recent essay of his on Marx's early work. Foster uses a reading of the Economic and Philosophical Manuscripts of 1844 to show how Marx was committed to critiquing and altering modernity's "productivist" bent from within modern structures-a parallel to SH's balancing of post-War planning schemes and eco-alternativism. In pursuing this line of reasoning, Foster tries to save Marx from environmentalist critiques of his instrumentalist view of humans and nature and from "postmodern relativists":

"It would be a mistake to see the answer to the ecological problem as one of rejecting "modernity" in the name of some abstract and amorphous "postmodernity" at the same time rejecting those modes of thought that provide a systematic critique of capitalism ... Rather, we must recognize that it is necessary to come to grips with modernity-above all capitalist modernity-and transform it". (Foster 2010, p. 238)

Therefore, there is a mutual socialist heritage to Sauerbruch Hutton's and this leading eco-socialist's views of modernity. Though SH are temperate in their tone, their theory of the body's experience of buildings as a form of environmental agency is radical. In "The Part Played by Labor in the Transition from Man to Ape" of 1876, Engels says that "we by 
no means rule over nature like a conqueror over a foreign people, like someone standing outside nature-but that we, with flesh, blood, and brain, belong to nature, and exist in its midst" (Engels 1978). For Sauerbruch and Hutton, buildings are a form of accumulation opposed to nature and can convey to bodies, "flesh, blood and brain," a non-quantifiable form of awareness about this opposition. This awareness, for $\mathrm{SH}$, is a component of both a building's use value and the basis of its status as sustainable architecture.

\section{Architecture's Lessons for Eco-Marxism}

Sauerbruch Hutton and Estudio Teddy Cruz are two very different architectural firms with two very different backgrounds. Yet what emerges from their work is a sense that radical structural critique is necessary and that the terms on which positive results might be achieved within flawed systems are necessarily ecological and, for practicing architects, necessarily limited. That the supposedly idealist, Western Marxist legacy of Adorno, Benjamin, and Brecht would provide an intellectual foundation for their ecological critique is surprising given the disrepute of Western Marxism among current ecologically minded Marxist theorists. In Marxist debates on the environment since the mid-1990s, John Bellamy Foster, editor of Monthly Review and author of Marx's Ecology (2000) has worked to show how the focus on consumption, which Jay has seen as characteristic of Western Marxism, wrongly displaces the question of sustainability from its rightful home in the sphere of production into the secondary sphere of experience (Foster and Clark 2010; Foster 2000). Régis Debray, perhaps Louis Althusser's most famous student, has similarly situated the locus of Marxism and ecology in terms of the revolutionary practice of Marxism from Marx himself to Mao and Guevara-again, a realm removed from the cultural critique derived, in recent architectural discourse, from Adorno and Benjamin (Debray 2007). Timothy Morton has echoed non-Marxist materialist eco-critics in lambasting aesthetic understandings of nature. He acknowledges the power of art, but says that aestheticized nature "will not remain effective for very long" as a convincing framework for encouraging sustainable behavior and creating sustainable economies (Morton 2010). Kenneth Pommeranz in New Left Review, also eschewing the aesthetic, has taken an in-depth journalistic approach to reveal what Marx can tell us about ecology and to develop a unified sensibility of financial and ecological crisis (Pommeranz 2009).

The eco-Marxist most sharply critical of the Western Marxist tradition is Paul Burkett, whose close analysis of Georg Lukács's dialectical thought, shows how that theorist forecloses upon the possibility of seeing social and natural sciences as a unity (Burkett 2001). While Burkett's assessment may certainly hold for Lukács's History and Class Consciousness, taking that one work as a stand-in for all of Western Marxism, as Burkett does, overemphasizes Lukács's influence and ignores the fundamentally aesthetic, experiential focus of Western Marxism, which Maria Gluck has traced through an account of the continuities in Lukács's thought across the divide of his supposed conversion from revolutionary aestheticism to revolutionary Marxism in the late 1910s (Gluck 1986). It is precisely at the nexus of aesthetics - as a realm of social experience-and the material dictates of political economy that SH's and Cruz's Marxist theories are situated. In this sense, however distantly and unconsciously, we might even view their work in light of attempts by Jean-Paul Sartre, Lukacs, and later Perry Anderson to bridge the experiential and the structural, the everyday and the historical in a Marxist theory that links the need for a critique of systems and the contradictory need to retain possibilities for human agency in everyday life.

There have been recent Marxist analyses of ecology that have placed aesthetic and experiential questions in the foreground. Imre Szeman uses Werner Herzog's and Ursula Biemann's films to trace the cultural ramifications of the fossil-fuel economy and point to the ways in which motion pictures can "generate other narratives about the future to come-an ecological politics which abandons the comforts of either apocalypse or business as usual" (Szeman 2010, p. 36) Szeman emphasizes, as a supplement to economic and political analysis, the "conceptual significance of raw inputs into the shape of capitalism" (Szeman 2010, p. 35). This approach takes films' narrative structures as interventions in the 
production of culture and as intertwined with the reproduction of economic systems. This discursive model is fruitful in opening avenues for seeing cultural production as political work, but does not separate film's particular mode of signing from that of theory; this is certainly the case where Szeman sees Herzog's Lessons of Darkness as articulating Marxist theorist Slavoj Žižek's idea of "ecology without nature" (Szeman 2010, p. 43).

Jacob Emery, in a recent article exploring the nexus of art, materialism and the environment, adopts and revises a specifically aesthetics-based approach from Fredric Jameson that sees art in terms of "allegorical materialism" as a "metaphorical expression of the hard historical facts of economic life, with which it advances in tandem" (Emery 2011, p. 119). The idea of the "tandem" motion of economy and art reveals that injecting an overt discussion of aesthetics into Marxist debates on the environment goes hand-in-hand with a defense of the kind dialectical thinking that influences Cruz and SH and which has come under attack from an increasing number of contemporary theorists (Strathausen 2009). However, "metaphor" and "allegory" do not lend themselves to easy integration into a materialist understanding of the role of art in political change and the painfully material exigencies of climate change. Emery, relying on a labor theory of the artwork, asserts that "we recognize artworks as such insofar as they are framed by work of other kinds" (Emery 2011, p. 121). A viewer, according to Emery, can look from an airplane window to the earth below and find evidence of human labor in forms wrought upon that earth by agriculture and industry. These "industrial traces" such as factories and farmers' fields lack the mark of specifically artistic intentionality, but can become art by being received as such in the sensory perception of the viewer. Analogously, self-consciously artistic cultural products can, by bridging the "useless" (as traditionally conceived) sphere of art to the usable material of everyday life, solicit subject positions that rest on the notion of art and work as a unity and thus can point in new and critical ways toward human beings' relationship to the non-human world. This fundamentally modernist position, derived from the interventions of the early Surrealists and the Dadaists, stretches the notion of artistic objecthood to fit a materialist understanding of history and political intervention and locates art's potential for environmental activism in the avant-garde modernism and Western Marxism of the late 1910s and early 1920s.

While Emery looks to conceptual art and forms created by the forces of political economy, architecture has long been seen as a natural meeting point of specifically artistic intentionality and raw utility in the material fabric of everyday life. This dual status has made architecture a fault line in Marxist debates, particularly the Western Marxist ones that eco-Marxism has tended to shun. Though charged with being idealists and aestheticists, Western Marxists like philosopher Ernst Bloch and playwright Bertolt Brecht saw architecture in materialist terms (Heynen 1999). They rejected the formalism of a modernist architecture that showcased its newness through visual experimentation. They insisted too that buildings exist as concrete reality and that, as such, their forms should be determined by the needs of specific communities of users and specific natural conditions. This last point meant that both Brecht and Bloch wanted architecture to evoke and embody place specificity. The relationship of the particular, material piece of history to history itself, because of local use patterns and ecology, becomes by extrapolation a question about the relationship of highly specific ecologies to globalization and its economic processes. Thus, Western Marxism and the eco-materialist and post-humanist discourses that thrive in English departments and have trickled, albeit in a highly idiosyncratic form, into architectural debates, share more than has been assumed (Harrison 2013).

Architecture is positioned on the border between representation and reality, and its disciplinary norms presuppose overlaps between art and everyday life long seen as being of political value. Ernst Plojhar's underappreciated Marxist theory of architecture Die Notwendigkeit der Architektur (The Necessity of Architecture 2001) rests on the premise that architecture's representational status and its status reality form a dialectical unity:

"Architecture and design [create] from [the existing material conditions of life] something new that differs from existing reality only insofar as it is a newly 
formed reality that is no less valid than what preceded it. This newly formed reality meets all the criteria of an objectively existing veritableness, but also represents a value judgment of the reality it reworked; it becomes self-contained as a new reality that solicits in turn new processes of appropriation that make new judgments of reality". (Plojhar 2001, p. 66)

While one detects in Plojhar's prose the mechanical quality that Carsten Strathausen attributes to dialectical thinking, the dialectic's positing of simultaneous and related separateness and unity can help reveal the unity of architecture's existence as reality and representation (Strathausen 2009). Bloch, whose architectural understanding mixes Marx with Roman architectural theorist Vitruvius, calls for an "authentic architecture, one that, in its own will to art, is at the same moment constructively and ornamentally permeated" (Bloch 2003, p. 517). Bloch pursues here a concept of visual form as content and of decoration not as facade or surface, but as integral component of a building's way of being and therefore, by extension, for Cruz and $\mathrm{SH}$, an integral part of architectural attempts to address the real, material problem of climate change.

Like their Western Marxist forebears, Cruz and Sauerbruch Hutton are staunch critics of empty formal gestures. They too recognize the role of agency in bringing forms into being and see the necessity of constructing a building's meaning through both design and use. The problem of climate change is for them a matter of a building's place in a politico-economic order and a matter of sensory perception by users who can, by working or dwelling in a space, see, feel, and produce critical knowledge about the relationship between human-made objects and human-caused ecological destruction. For them, a building can convey to users at the bodily level something about the essence of sustainability in a way both useful and formal.

Cruz, in seeking an architecture appropriate to the social and ecological context of the San Diego-Tijuana border, blends Brecht's 1920s critique of institutionality, which Hays had seen as analogous to Hannes Meyer's architectural approach, and Adorno's indictment of functionalist architecture. In so doing, Cruz critiques global capitalism's ecological, urban, and human consequences as a unity and seeks a mode of architecture that can forge new institutions and reinstate collective agency as a force for ecological good (Hays 1995, pp. 25-29). Sauerbruch and Hutton similarly want to reconcile the organic and the planned. They see the history of architectural modernism as a dialectic of critique and institutionality based upon which they imagine non-commodified forms of sustainability and retain bodily pleasure as a central component of architecture's use value. These architects can help Marxists concerned about ecology and design scholars concerned about sustainability understand modernity as a useful category that must be subjected to continuous dialectical refinement; Western Marxist ideas such as consciousness, alienation, and experience-core components of modernist artworks—can have a role in pushing forward ecological critique. For Cruz and SH, architecture's relationship to ecology is inseparable from the fundamental question of why the built world looks and feels the way it does. Their theoretical work, representing a continuation of Marxist concepts in contemporary architectural discourse, reveals perception and use as forms of labor that should be taken into account by eco-Marxists whose primary interest is in political economy and architects whose central concern is ecology.

\section{Conclusions: Mass Culture and a Framework for Sustainable Design}

Therefore, these two architectural firms have worked to integrate certain aspects of Marxist theory in their practice. I have, in the course of this essay, used the term "Western Marxism" in a somewhat monolithic way to highlight the centrality of experiential and aesthetic implications of Marxism within the architectural discourse I have traced. There are, of course, significant disagreements about those implications among the figures I have mentioned, most notably between Adorno and Brecht and between Adorno and Benjamin. Just to summarize the highly familiar difference: Brecht and Benjamin in the time around 1932-4 both took a more favorable view of modern mass culture and saw 
possibilities of self-organization and agency in working class attempts to use new media for revolutionary purposes. Adorno, by contrast, saw this as a "vulgar" application of dialectics and saw instead the steadfast embeddedness of cinema and radio in reified capitalist structures within which only resistive, ambiguous, challenging artworks (and of course theories!) could keep alive the future-oriented possibility of complete structural change (Wilke 1988). This contrast seems so very characteristic of the context from which it emerged - one in which new media were rising in tandem with radical right wing politics and the increasingly "damaged" quality of everyday life. In moments where it is taken out of its original contexts, it has been, as was fashionable in the 1990s, used to delineate the boundary between the Adornean commitment to high-modernism and Ideologiekritik of media documents on the one hand and a Benjaminian and Brechtian emphasis on play, agency, and the dialectical quality of modernity's detritus.

At first glance, this set of contradictions seems a thing of the past in a world where palm oil from Malaysia and timber from Brazil are harvested using slave labor even as the Atlantic hurricane season is proving the most active on record and wildfires have displaced hundreds of thousands of people in Oregon and California. Yet the problems faced by the left in working, as sections of the left were in the 1930s, effectively for the survival of human beings, are in many ways similar. It should also be remembered that Sartre and Lukács in the 1960s were working toward a social ontology of being that could account for the larger movements of history and systems on the one hand and individual agency and the importance of the empirical experience of reality on the other (with its attendant mix of emotions and consciousness). They saw this as a key endeavor precisely because it did not merely defer revolutionary possibility to a utopian future contained in a structural component of contemporary society (such as experimental art). Nor did it fetishize the experiential and separate analysis from practice.

Therefore, as eco-materialists quite rightly sound alarm bells, Marxist theory resolutely asks to whom they must be sounded, who is responsible for climate action including structural economic changes, and how a practice might be shaped in everyday life between the traditional street protest on the one hand and the staid tradition of the ballot box on the other-the two seemingly always inadequate responses to climate change left to people living in democracies. It turns out that such a practice is not always found in the separate realities of alternative movements disconnected from the realities of the masses of human beings. Nor is it found in only the cognitively demanding articulation of formal complexity in art in connection to forms through which capitalism alienates us from ourselves. Teddy Cruz's architecture work does not escape the bounds of capital—neither in its institutional frameworks nor, least of all, in its approach to form. However, instead of rejecting mass culture, Cruz attempts to intervene in it and shape consciousness through organization at what Marxists would see as the "base" rather than the superstructure. Cruz is at the center of UC San Diego's "Community Stations" project, which acts as a conduit for community advocacy organizations in the small, impoverished towns around the San Diego-Tijuana border. Experts from the University's social science and design department help the organizations seek funding from public and private sources to develop projects that meet vital needs of the each municipality_including, of course, ecological needs. The first of these "Stations" has just been completed at San Ysidro, California. It is at its heart a social housing complex designed at a scale that matches that of the surrounding community and that includes public spaces for theater (in a repurposed 1920s church) and two pavilions housing social and health services. For Cruz, this is fundamentally about attempting to "increase community capacity for political action" by reducing the gap between the University and the working class and by heightening work class sense of agency in relation to small and large scale social and ecological problems (Cruz 2020). It comes as no surprise then that another of the "Community Stations" Cruz is involved in designing will be a four-acre park and education center devoted to increasing awareness of the problems presented by climate change within the working class communities of southern California and showing the forms that political action might take in helping bring about structural 
change. If Brecht sought to create a new form of political theater out of the practices of working class theater troupes in the 1930-1933 period and if Benjamin saw the most radical book in Russia after the revolution as the early childhood reading primer, Cruz too sees in small-scale, repeated mass action the seeds of a potentially revolutionary practice. This is a model that eschews the transcendent and naively liberal appeal to personal responsibility and near-nihilistic handwringing about the scale of structural problems to be solved. Cruz's Brechtian model of combined social and climate agency that is realistic about institutions and measures itself according to the conditions of the working class is perhaps worth consideration for eco-Marxists and other eco-materialists alike.

Additionally, while Sauerbruch Hutton in the highly dialectical synthesis of their thought sometimes take a tone that sounds more moderate than that which Cruz adopts, they nevertheless engage the problem of emotions in everyday life head on in ways that are quite radical. They tend, like Adorno, to be more abstract than Cruz, thinking in terms of users in general or "the bodies of users" rather than in the sociologically concrete terms of Cruz. Additionally, certainly it must be said too that, while Sauerbruch Hutton have designed an office tower for a social housing agency and have created a social housing scheme to be built on the grounds of a former US military installation, they also have a number of corporate clients and are more globally glitzy firm. Yet it was about precisely this firm that the great radical filmmaker Harun Farocki decided to make a film in 2013. Farocki filmed three months in the life of the firm as it was working to create a design for a virtual reality center in Laval, France and while the esoteric quality of the firm's conversations certainly create a few critical moments, Farocki ultimately saw in the architects' discussion of the issues of representation and mediatization present in the project a highly positive dialectic:

"The structures of these two architects appeal to me. They are lavish with ideas while remaining dedicated to ecological efficiency. They are playful without being arbitrary. They are bound to the formal language of modernity without being dogmatic". (Farocki 2015)

Indeed, closer inspection of a project such as the Airut neighborhood of Helsinki, for which SH created a plan and designed structures in 2012 reveals a tense dialectic of different social, economic, and aesthetic factors that uses architecture to reveal the utopian elements in capitalism itself, which Marx never shied away from. The neighborhood was sponsored by the Helsinki city government and allied organizations and was specifically commissioned as a prototype for urban development with the smallest possible carbon footprint. Matthias Sauerbruch, of course, has acknowledged in his theoretical writings that not building at all is always the most sustainable option-and the firm has been remarkably committed to adaptive reuse. He also asserts that ecological catastrophe can "not be overcome through inaction." Instead, he affirms the need for human creativity: "In the end, we do in fact need this or that invention that then will lead to the rebuilding of certain aspects of the city." These aspects include, among other things, maintenance of a comprehensive green infrastructure along with a clear change in social relationships, among other things, through the reorganization of work" (Sauerbruch 2020). Farocki saw in the firm an affirmation of architecture's - and by extension all art's - potential power to intervene in economies and everyday life both physically and symbolically. At Airut, the Y-shaped public plazas and the irregular shape of the buildings, the sustainable nature of the retail component, the firm's diligent calculations of the carbon footprint of the buildings' systems but also of the materials that go into them represent the fruits of scientific research and economic calculus even as they act as an urban intervention that balances the dialectic between novelty and history. They are a criticism and a challenge to find new ways of everyday living within our "damaged" world. A kind of reverse "Minima Moralia" in bricks and mortar, the project offers a utopian image of radically changed everyday life in which "social relationships" and even "work" itself are changed in ways that minimize the extent to which they further human self-destruction. 
Therefore, the legacy of Adorno, Brecht, and Benjamin does have something to do with our era of climate change. Their work contains critical tools that help us expose the mechanics of self-destructive systems and chart their effects in the realm of everyday life. They offer paths forward, necessarily limited just as our own are, for staking claims to agency within totalizing systems. Their focus on aesthetics and experience shows that the improvement of human existence depends on human creativity which is intertwined with but not subsumed by economic calculus. The words and feelings that go along with the drive to forge sustainable systems and sustainable everyday lives matter, for they stand in an intimate dialectical relationship with rational consciousness and economic structure. The legacy of Western Marxism in today's green architecture-however diluted-is still a platform for ruminating on the possibilities and limits political agency-the agency needed for human survival.

Funding: This research received no external funding.

Institutional Review Board Statement: Not applicable.

Informed Consent Statement: Not applicable.

Data Availability Statement: Not applicable.

Conflicts of Interest: The author declares no conflict of interest.

\section{References}

Adorno, Theodor. 1997. Functionalism Today. In Rethinking Architecture. Edited by Neil Leach. London: Routledge, pp. 6-19.

Benjamin, Walter. 2009. Surrealism. In One-Way Street and Other Writings. Edited by Amit Chaudhuri. New York: Penguin, pp. 143-60. Bergdoll, Barry. 2009. Sustainable Colours and Non-Standard Forms: On Sauerbruch Hutton's Recent Work. 2G 52: 16-27.

Bloch, Ernst. 2003. Die Bebauung des Hohlraums. In Architekturtheorie im 20. Jahrhundert: Eine Kritische Anthologie. Edited by Aḱos Moravánszky. Wien: Springer, pp. 517-18.

Burkett, Paul. 2001. Lukács on Science. Economic and Political Weekly 36: 4485-89.

Cruz, Teddy. 2009. A City Made of Waste. The Nation, February 16.

Cruz, Teddy. 2010a. Camouflaging Disaster: 60 Linear Miles of Local Transborder Urban Conflict. In Beyond Shelter: Architecture and Human Dignity. Edited by Marie J. Aquilino. New York: Metropolis Books.

Cruz, Teddy. 2010b. Design ops-A Conversation between Teddy Cruz and Jonathan Tate. In Architecture at the Edge of Everything Else. Edited by Esther Choi and Marrikka Trotter. Cambridge: Workbooks and MIT Press.

Cruz, Teddy. 2011. Letter to the Profession of Architecture. In New Directions in Sustainable Design. Edited by Adrian Parr and Michael Zaretsky. New York: Routledge, pp. 3-5.

Cruz, Teddy. 2020. UCSD-CASA Community Station. Website for the UCSD Center for Global Justice. Available online: http: //gjustice.ucsd.edu/casa/ (accessed on 1 October 2020).

Cupers, Kenny. 2014. Where Is the Social Project? Journal of Architectural Education 68: 6-8. [CrossRef]

Debray, Régis. 2007. Socialism: A Life-Cycle. New Left Review 46: 5-28.

Emery, Jacob. 2011. Art of the Industrial Trace. New Left Review 71: 117-33.

Engels, Friedrich. 1978. The Part Played by Labor in the Transition from Man to Ape. Moscow: Progress Publishers.

Farocki, Harun. 2015. Interview. Quoted in Gallanti, Fabrizio. Harun Farocki and his Film about Sauerbruch Hutton. Abitare. February. Available online: https://www.abitare.it/en/design-en/visual-design-en/2015/02/02/harun-farocki-film-sauerbruch-hutton/ (accessed on 1 October 2020).

Foster, John Bellamy, and Brett Clark. 2010. The Ecology of Consumption: A Critique of Economic Malthusianism. Polygraph 22: 113-32.

Foster, John Bellamy. 2000. Marx's Ecology: Materialism and Nature. New York: Monthly Review Press.

Foster, John Bellamy. 2010. Marx and the Environment. In Marx Today: Selected Works and Recent Debates. Edited by John F. Sitton. New York: Palgrave Macmillan, pp. 229-40.

Gluck, Maria. 1986. Toward a Historical Definition of Modernism: Georg Lukács and the Avant Garde. The Journal of Modern History 58: 845-82. [CrossRef]

Harrison, Ariane Lourie. 2013. Architectural Theories of the Environment: Posthuman Territories. New York: Routledge.

Hays, K. Michael. 1995. Modernism and the Posthumanist Subject: The Architecture of Hannes Meyer and Ludwig Hilbersheimer. Cambridge: MIT Press.

Heynen, Hilde. 1999. Architecture and Modernity: A Critique. Cambridge: MIT Press.

Highmore, Ben. 2010. Streets in the Air: Alison and Peter Smithson's Doorstep Philosophy. In Neo-Avant-Garde and Postmodern: Postwar Architecture in Britain and Beyond. Edited by Mark Crinson and Claire Zimmerman. New Haven: Yale Center for British Art, pp. 79-100. 
Hyde, Timothy. 2015. Architecture, Modernity, Crisis. Journal of Architectural Education 69: 2-3. [CrossRef]

Ingersoll, Richard. 1996. Second Nature: On the Social Bond of Ecology and Architecture. In Reconstructing Architecture: Critical Discourses and Social Practices. Edited by Thomas A. Dutton and Lian Hurst Mann. Minneapolis: University of Minnesota Press, pp. 119-57.

Jay, Martin. 1984. Marxism and Totality: The Adventures of a Concept from Lukács to Habermas. Berkeley: University of California Press.

Khan, Ahmed Zaib, Han Vandevyvere, and Karen Allacker. 2013. Design for the Ecological Age: Rethinking the Role of Sustainability in Architectural Education. Journal of Architectural Education 67: 175-85. [CrossRef]

Leach, Neil, ed. 1997. Rethinking Architecture: A Reader in Cultural Theory. New York: Routledge.

Lefebvre, Henri. 1995. Introduction to Modernity: Twelve Preludes, September 1959-May 1961. New York: Verso.

Mallgrave, Harry. 2009. Modern Architectural Theory: A Historical Survey, 1673-1968. Cambridge: Cambridge University Press.

Merrifield, Andy. 2002. Metromarxism: A Marxist Tale of the City. New York: Routledge.

Morton, Timothy. 2010. Ecology after Capitalism. Polygraph 22: 46-59.

Neveu, Marc J. 2015. Crisis, Crisis Everywhere. Journal of Architectural Education 69: 1. [CrossRef]

Ockman, Joan, ed. 1993. Architecture Culture: 1943-1968. New York: Rizzoli.

Owen, Ceridwen, Kim Dovey, and Wiryono Raharjo. 2013. Teaching Informal Urbanism: Simulating Informal Settlement Practices in the Design Studio. Journal of Architectural Education 67: 214-23. [CrossRef]

Plojhar, Ernst. 2001. Die Notwendigkeit der Architektur. Vienna: Promedia.

Pommeranz, Kenneth. 2009. The Great Himalayan Watershed: Agrarian Crisis, Megadams and the Environment. New Left Review 58: 5-39.

Sauerbruch, Matthias, and Louisa Hutton. 2006. What Does Sustainability Look Like? In Sauerbruch Hutton: Archive. Baden: Lars Müller.

Sauerbruch, Matthias. 2020. Zum Thema: Heimat. On the Website of the Architecture Firm, Sauerbruch Hutton. Available online: http:/ / www.sauerbruchhutton.de/de/essay/zum-thema-heimat (accessed on 1 October 2020).

Smithson, Alison, and Peter Smithson. 1988. Whatever Happened to Metabolism. The Japan Architect, April.

Stanek, Łukasz. 2013. Henri Lefebvre: For and Against the User. In Use Matters: An Alternative History of Architecture. Edited by Kenny Cupers. New York: Routledge, pp. 139-52.

Strathausen, Carsten. 2009. Introduction. In A Leftist Ontology: Beyond Relativism and Identity Politics. Edited by Carsten Strathausen. Minneapolis: University of Minnesota Press, pp. xix-xlii.

Swyngedouw, Erik. 2005. Metabolic Urbanization: The Making of Cyborg Cities. In The Nature of Cities. Urban Political Ecology and the Politics of Urban Metabolism. Edited by Nik Heynen, Maria Kaika and Erik Swyngedouw. London: Routledge, pp. 21-40.

Szeman, Imre. 2010. The Cultural Politics of Oil. Polygraph 22: 33-46.

Tafuri, Manfredo, and Francesco Dal Co. Modern Architecture. New York: Abrams.

Van den Heuvel, Dirk. 2013. Alison and Peter Smithson: A Brutalist Story, Involving the House, the City and the Everyday (Plus a Couple of Other Things). Ph.D. dissertation, TU Delft, Delft, The Netherlands.

Vidler, Anthony. 2014. Troubles in Theory V: The Brutalist Moment(s). The Architectural Review, January 30.

Webster, Helena, ed. 1997. Modernism without Rhetoric: Essays on the Work of Alison and Peter Smithson. London: Academy Editions.

Wilke, Sabine. 1988. Torn Halves of an Integral Freedom: Adorno and Benjamin Reading Popular Culture. Journal of Comparative Literature and Aesthetics XI: 39-56.

“Wutmieter auf der Straße”. 2011. Wutmieter auf der Straße. Die Tageszeitung, April 9. 